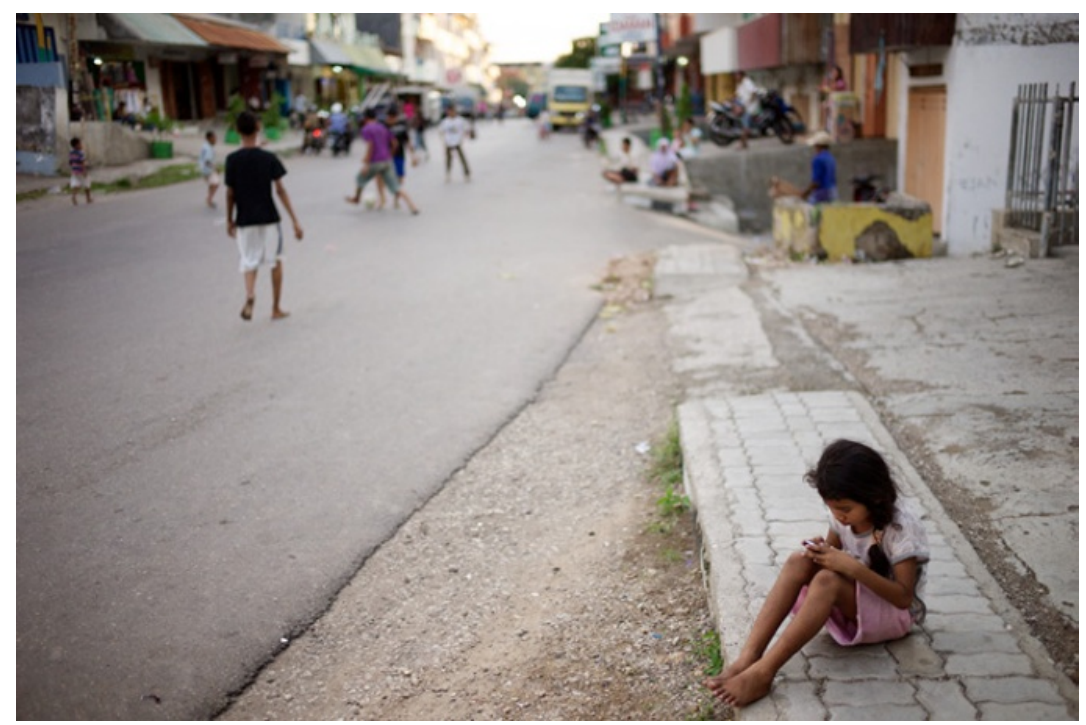

Fig 3: KUPANG: Girl absorbed in a cell phone game while older kids play street soccer in downtown kupang. Cell phones, with radios, games, music, cameras, and web access, are the new babysitters all over Indonesia.

June 2010: photo by S. Chris Brown 


\title{
CLASS MOBIL: CIRCULATION OF CHILDREN IN THE MAKING OF MIDDLE INDONESIA
}

\author{
Jan Newberry
}

Mas Hadi had bought a car. This was the biggest news in the kampung neighbourhood when I visited in 2006. ${ }^{1}$ The new car, or mobil, was actually a used minivan. The listing of its many flaws and its description as bad, or jelek, did not mask his family's glee in having it. The mobil was in fact a great boon to this family, living a stone's throw from the Yogyakarta kraton, the palace of the sultan. Although better off than some of the downtown kampung, this neighbourhood was likewise home to densely packed houses of the urban lower classes (Robison 1996). Site of innumerable small, home-based enterprises along with low-level civil servants, clerks and teachers, this kampung neighbourhood was more often described by locals as the home of many of the faithful servants of the sultan, the abdi dalem. It also served as residence for scrappy lower-class entrepreneurs, crooks and schemers typical of urban kampung. For all of them, the arrival of a mobil marked the attainment of a new level of consumption and the possibility of middle-class mobility. Yet, the car also marked a kind of family resource whose use demonstrated patterns of kampung kinship, even as it showed a widening class gap within the family. Although Mas Hadi had moved to a new housing development with his young family, he left the mobil in the kampung at his mother's house where it was used by his large extended family. Every day he brought his young son to this house, centre of a dense network of kin, so that Ari would attend the same neighbourhood school Mas Hadi himself had attended and so experience an upbringing much like his own.

Kampung are urban enclaves understood to be home to lower-class Javanese who are rough and unrefined (kasar in Indonesian). In contrast to wealthier, more refined street-side residents, they are described as

\footnotetext{
1 Located in the central court city of Yogyakarta, Central Java, Indonesia, this kampung neighbourhood has been the site of my ethnographic fieldwork since the early 199os. Mas Hadi was the oldest son of the kampung family that had served as my most important source of social support, both as personal support and as valued cultural interpreters. I gratefully acknowledge the support from KITLV's Middle Indonesia project, and from the Asia Research Institute of the National University of Singapore.
}

(C) JAN NEWBERRY, 2014.

This is an open access chapter distributed under the terms of the Creative Commons Attribution-Noncommercial-NonDerivative 3.0 Unported (CC-BY-NC-ND 3.0) License. 
'little people' (wong cilik in Javanese ${ }^{2}$ ) (Guinness 1991). The kampung class has typically not been described as part of the Indonesian middle. ${ }^{3}$ Yet by considering the middle from the perspective of these lower-class urbanites, sources of class differentiation and definition can be seen from another perspective, one that counters normative descriptions of the middle class as part of modernization even as it resituates culture understood in relation to production in the manner of Bourdieu (1984), and earlier of Raymond Williams $(1961,1977){ }^{4}$ The kampung class has been generally neglected in treatments of class in Indonesia (but see Guinness 1986, 1991, 2009; J. Sullivan 1980, 1986, 1992; N. Sullivan 1983, 1994). More to the point here, the role of family practices and child-rearing as markers of class and sources of its reproduction have not been placed at the centre of any consideration of class.

The kampung class is defined in large measure by being an urban form, and in the following it is approached through the lens of urban family and kinship. Class mobility, then, refers to the spatial mobility afforded by the mobil, but also to changing class position. This chapter identifies both the constraints on kampung mobility and its structural twin, forced mobility. The socialization of kampung children, and the circulation of children to improve family circumstances, becomes a window on forms of classed embodiment.

\section{See the Middle from the Kampung Class}

Attention to the kampung class interrupts the conversation on the middle class in Indonesia. Hildred Geertz (1963:35), whose work forms a significant part of the following account, described the urban environment in midcentury Indonesia as producing a 'metropolitan superculture' of urban elites. More recent attention to the middle class in Indonesia has focused on its patterns of consumption (Shiraishi 2004) and the divergence in the

2 Javanese is the local language. Unless otherwise noted, interviews were conducted in the national language.

3 The CIA's World Factbook (2012) puts Indonesian urbanization at $44 \%$ of the population. The World Bank (2012) describes Java as $67 \%$ urbanized, with a total of 78 million people living in cities, and predicts $61 \%$ urbanization for the country as a whole in 2025 . This same document notes that $32 \%$ of the poor were in urban areas in 1999, the highest ratio in developing East Asia (to which Indonesia belongs in this report).

4 The analysis of culture in the Marxian mode (Corrigan and Sayer 1985; Roseberry 1989; Thompson 1967; Willis 1977) has fallen out of favour in anthropology, although it remains strong in cultural studies. Recent work on the anthropology of the state touches on these issues from a different angle (Steinmetz 1999; Blom Hansen and Stepputat 2001). 
Indonesian middle class from standard descriptions of a middle class in the fashion of the European bourgeoisie (Heryanto 2003; see also Crouch 1986). Its self-conscious fashioning as a class and its democratic potential have been assessed (Dick 1985; Crouch 1994). While political science may have 'annexed' the definitions of the middle at one point (Van Leeuwen 2011), a cultural-studies approach that considers consumption, style and aesthetics seems to have gained a foothold as well. What remains little attended to is the practical consciousness of embodied culture as an element of class, and the key role of kinship and family in its reproduction.

This chapter adopts a different tack for understanding middle Indonesia by describing it from the perspective of the kampung class in Central Java. This class-from-below approach helps define the edges of the emerging middle (cf. Heryanto 2003). At the same time its ethnographic grounding in Central Java demonstrates the ongoing reproduction of particular forms of Javanese flexibility that illustrate the structuration of shared cultural disposition (Giddens 1984). The work presented here suggests that one of the untold stories of Indonesia is the role of the kampung class in conferring stability in its long-term-growth trajectory. It serves as a bulwark against extremist political violence (see also Van Klinken 2009b).

Approaching the middle through the kampung class also demonstrates that production in the constitution of this class-in-the-making must not be forgotten. In contrast to work by Beatty (2002), who notes a fundamental Javanese relativism that is not contingent upon structural conditions of economy and politics, this work suggests that the kampung class is made in large measure through its role in the Indonesian economy. That is, the kampung class is constituted in part through class mobility and constraint that derives from its structural position as much as agentive patterns of consumption. Yet, this production cannot be divorced from a habitus of shared lifestyle, a self-conscious culture of community and embodied forms of distinction (Bourdieu 1984). The work presented here suggests that the kampung class is profoundly shaped through its economic role in the Indonesian economy, but also by forms of practical consciousness that extend and reproduce this class position and produce a remarkably durable structure of feeling (R. Williams 1961, 1977).

In the following, as one means to map the topology of the middle in Indonesia, the twin pulls of knowing one's place and seeking to transcend it are located at three points: the production of kampung consciousness, the socialization of kampung children and the circulation of children through adoptive relationships (anak angkat). 


\section{The Production of Kampung Consciousness}

In the 1990s, the emergence of a self-conscious middle class-for-itself that took a particularly 'intellectual' approach to democratization was matched with the rapid growth of new industrial capacity as well as gated suburban housing settlements in Jakarta's peri-urban periphery (Van Leeuwen 2011; Kusno 2000). Van Leeuwen traces the history of scholarship on Indonesia's middle class to Hildred Geertz's (1961) early identification of an urban middle class. The connection to Geertz is doubly significant here given her work on child socialization attended to below. The kampung class is generally overlooked as a political force, but instead is taken to represent backwardness (Kusno 200o) and the site for intervention to alleviate social problems. Yet, forms of kampung production and the related forms of embodied class consciousness may provide important stabilizing effects as the kampung class serves as counterweight to rapid change, even as its reproduction serves to anchor people in place.

Indonesia appears to be weathering the global financial downturn in better shape than one might have expected given the tumultuous effects of the Asian financial crisis of the late 199os. The stability of the economy can be related to several factors. President Susilo Bambang Yudhoyono cracked down on unrest and opened the country to increased foreign direct investment. On the other hand, it might be argued that the success of the economy requires less explanation than the lack of its success in the post-Independence era, given Indonesia's rich natural resources. Crony capitalism (Robison and Hadiz 2004) and high levels of corruption are typically identified as root causes, while incoherent management due to regional autonomy played a role as well (Schulte Nordholt and Van Klinken 2007b). One element in Indonesia's economic stability that has received less attention comprises the very small, home-based industries in kampung neighbourhoods. As Hadiz (2002) notes, Indonesia's competitive advantage has long relied on its labour surplus economy. Southeast Asia generally has been a source of cheap, often female, labour on global assembly lines (Wolf 1992; Hill 1996) and has exported female domestic labour throughout Asia and the Middle East. But the largely female workforce in micro-industries has received less attention.

In an argument developed elsewhere (Newberry 2006, 2007), kampung neighbourhoods are described as the site of the reproduction of a large reserve army of labour, in part through social welfare programmes that harness the voluntary labour of women. State administration of 
communities under the New Order had the effect of mobilizing women as unpaid social welfare labour. It simultaneously positioned them in the home as wives and mothers who also supported husbands and children who were half-employed, occasionally employed, employed in low-skill labour or simply unemployed. Programmes such as the national housewives association (Pembinaan Kesejahateraan Keluarga, PKK), which are underwritten by local forms of administration below the civil service, combine with the ideal of a supportive home community to support the reproduction of very cheap labour.

This aspect of the state-ordered gendered division of labour is evident in the provision of small amounts of credit and grants along with education on small industries (usaha kerajinan kecil). Kellett et al. (2001) have used the term 'micro-scale home-based enterprises' (HBE) to describe these industries that blur and reconfigure the 'spatial and conceptual boundaries between work and home, between production and reproduction' in order to generate income and sustain themselves. The Indonesian Central Statistics Agency (Badan Pusat Statistik, BPS) has defined microenterprises (called cottage industries) as those with 1-4 workers; small enterprises as those with $5^{-19}$; medium enterprises as those with 20-99; and large enterprises as those with over 100 workers (Berry, Rodriguez and Sandee 2001). Kampung are the site for the full range of these enterprises, including even some large ones. In the 1996 census, micro-enterprises dominated in number of workers, as they did in the past. Micro-enterprises represented $75.4 \%$ of workers in manufacturing in 1975 (3,900,000 workers); $49.3 \%$ in 1986 (2,714,00o workers); and $39.9 \%$ in 1996 (4,076,ooo; Berry, Rodriguez and Sandee 2001:365). Yet, as Berry, Rodriguez and Sandee (2001:365) note, 'in 1996, 40\% of all workers were found in units of under 5 workers'. Brata (2007) demonstrates the continuing importance of small enterprises by citing 2006 statistics that $91 \%$ of employment in Indonesia is in small enterprises. The non-governmental sphere has also played a role in encouraging the development of these small-scale industries as part of a global model aimed at grassroots development, along the lines, for example, of micro-credit programmes.

The identification of the kampung as a class formation, then, is derived in part from this involution in economic activities through the proliferation of small industries within them. It is central to the provision of one of Indonesia's key comparative advantages: cheap labour. And whether this labour materializes as factory-wage-earning labour, or quickly absorbed and dismissed manual labour, or overseas domestic labour, or local small industries labour, the advantage of cheap reproduction is clear (Guinness 
2009; Meillassoux 1981). The key thing here is that the labour produced in kampung is cheap because it is precarious and informal.

Global regimes of flexible accumulation and late capitalism are cited as the cause of increased labour precarity (Arnold 2008; Harvey 1990; Ong 1999). This informalization of labour is a continuous process of undermining labour stability and the prospect of secure, well-remunerated work and benefits. Such an analysis reflects a nostalgia for the Fordist compromise that ruled the developed north Atlantic during the midtwentieth century. Yet, no such nostalgia is possible in Java, where labour has long been informal and where, to the contrary, it might be argued that kampung forms of precarious, informal labour have long served to stabilize, manage and reproduce labour. That is to say, the kampung economy, rather ironically, provides stability as it underwrites the precarity, or flexibility, of labour in Indonesia.

A young girl in the extended family described here moved between households in a relationship that looks much like the anak angkat relationships detailed later. I had known her since she was a child. In my most recent fieldtrip, I learned that she was working in a factory in Bekasi, an industrial area on the outskirts of Jakarta. Meanwhile a variety of livelihood activities were occurring in the house where she was born and raised. They included cooking candy to be sold, name card printing, piecework labour, haircutting, a small snack and drink stall, numbers games, as well as the provision of spiritual help to win at them. What then is remarkable, is not that a young woman had gone to Jakarta to work in a factory, but rather the myriad, legal and illegal, informal jobs of those who stayed put. They were surviving at the edge of the formal economy as alwaysavailable labour for whatever industry developed in the neighbourhood. No one expected this young woman to last at her factory job for very long, and it was understood that she could return home to be supported, as all the rest of her siblings were, by the make-work kampung labour of their mother and her relatives.

As significant as the precarity of labour for the analysis proposed here is the reproduction of a particular kampung consciousness. Indeed, it is here that the role of the kampung class in defining the middle is made apparent. An ideal of mutual self-help, or gotong royong, and community values of mutual obligation and support are key parts of kampung identity (Bowen 1986; see also Guinness 2009; Warouw 2006). Ultimately, this rhetoric of community self-help validates the reproduction of those who are under- and unemployed, even as it legitimizes women's gendered labour in support of their families and communities. These lower-class 
enclaves are bounded in more than one way: by the architecture of streets and walls; by forms of community organization, such as the neighbourhood civil security patrol (ronda); by administrative management by municipal authorities; but also by modes of dress, interaction and social relationships. In some contrast to Hildred Geertz's observation (1963) of formlessness in the early 196os, kampung neighbourhoods are organized, formally and informally, at a variety of levels. Thus, the sense of a bounded community has multiple, reinforcing sources. Perhaps the most telling is the use of kampung as a marker of a particular kind of class identity, one that is both cause and consequence of these boundaries.

To say that one is a 'kampung' person is to suggest a lower-class socioeconomic position, whether used by insider or outsider. Yet, when people inside these densely packed neighbourhoods use this term, it connotes familiarity and comfort with a particular style of life, one predicated on close observation of particular repertoires of behaviour. Kampung people are taken to be involved in one another's lives, whether as guardian of neighbourhood moral dictates or as collaborator in local schemes, for good or ill. Attendance at kampung life rite events and other community ritual events is expected. Sending money rather than providing communal labour at such events elaborates this set of behaviours. That is, to send money is to suggest a higher socio-economic standing, and while often understood as not sufficiently kampung, the people who can send envelopes of money also represent what is desired by many in the neighbourhood. This ambivalence between desire and suspicion of the wealthy is persistent in the kampung, serving again to mark incipient class boundaries.

The highly nuanced and subtle distinctions formed around the idea of kampung are evidence of the complexities of class, even as they illustrate how the positive affirmation of community membership by some can quickly become denigration by others. To call someone wong kampung (kampung person, Javanese) has a positive valence as insider, one of us, someone who understands what the kampung represents in a kind of resistance to normative middle-class respectability and pretensions. Yet to say wong kampung-an (person who acts like they are from the kampung), that is to say, a person with a kampung mentality, is to shift this discourse to the pejorative and the speaker to an outsider. A further contrast makes this clearer. Javanese colleagues noted that to be told: 'aja desani' ('don't act like you are from the countryside', Javanese) carries the meaning of not acting too humble, too self-effacing, as a rural peasant might in the company of those with higher standing. The contrast between 
rural and urban as embodying different values is clear when we contrast this humility with the effect of being told:'jangan kampungan' (Indonesian for 'don't act like a kampung person'). Here the connotation is of being rough, unrefined, not well-bred - kasar. Poverty and lower-class standing is implied in both examples, but the contrast between humble and vulgar is a key one. The use of these phrases, whether by kampung insider or outsider, effectively celebrates - as well as denigrates the countryside, while the urban poor are unambiguously described in negative terms.

In other words, kampung is a form of class consciousness, one that cuts two ways. While the word is used to register lower-class identity, kampung neighbours use it as a lash against those who fail to conform to kampung life, and against those whose class position is higher and therefore unmoored from the realities of kampung life. As such, kampung forms of distinction serve to mark the edges of the middle through conduct that simultaneously confirms class consciousness and registers a desire for the middle class. In many ways, kampung consciousness is fundamentally split: always looking forward to a modernizing urbanism while simultaneously gazing with nostalgia at a rural, village past.

Yet, the urban character of kampung is crucial here, even as these urban enclaves often blur the lines between rural traditional values and urban cosmopolitan ones. The New Order made good use of the village rhetoric to organize and govern these urban communities. As a consequence, the absorptive capacities of the kampung are not understood by kampung dwellers as a response to global demand for flexible labour, but instead as evidence of the still strong, rural Javanese values of sharing and mutual support. As I have described elsewhere (Newberry 2006, 2007; and see Breman 1980, 1988), the origins of the village imaginary are less important here than their continued reproduction through everyday social practices and their durability as New Order forms of governmentality. While it is true that rural Java also serves as a reserve of flexible and surplus labour, it is the urban kampung in its proximity to urban middle-class lives that lights up the divide between the lower class and the middle.

Kampung serve, then, not only as meaningful containers for particular types of economic activities, including those from which the state and the Indonesian economy derive great benefit, but also as a container for the domestic reproduction of particular forms of classed experience. Patterns of social engagement and particular repertoires of ritual and everyday experience reinforce membership even as they draw lines between inside and outside. This boundary-making is materialized in spatial practices that give material form to the kampung class. That is, kampung are not 
only social formations but spatial ones as well. In some measure, kampung work as whole social universes whose boundaries are re-inscribed on a daily basis through shared forms of belief, practice and life.

In the following, the inculcation of some of the values associated with the kampung class through child-rearing will be considered to demonstrate the embodiment of kampung consciousness and how it relates to social mobility.

\section{Diffuse and Enduring Forms of Respectful Embodiment}

The year the mobil arrived, much of family life seemed oriented around admiring it. The improvement of the kampung house had included the addition of a deep, tiled front porch, a much-favoured aspect of kampung houses because it allows for catching cool breezes in the afternoon and monitoring the comings and goings of neighbours down the street. On one of my visits, Mas Hadi's family was at the house with their young son, Ari. I had brought a present for him, as I did for the other children of the family. Because he was so young, about four years old, he was extremely shy in front of me. Rather than leave the mobil, which was parked next to the porch and where he often sat in the driver's seat to watch the world through the windshield, Ari looked at me with fear and trepidation. Despite his deep desire for the toy I had bought, he was unable to come and greet me to receive it. That is, he refused to salam, which meant approaching me to respectfully take my hand and bring the back of it to his forehead. One constant refrain when around children is the command to salam when arriving and leaving respected older people. Young children frequently refuse if shy around the adult, and the repeated, often frantic-sounding urging to salam, salam, indicates that attaining this respectful form of embodiment is quite important.

Javanese comportment in the kampung still emphasizes refinement, and the desire to be alus, or refined, is one that has often been noted for the Javanese. Alus is typically opposed to kasar, or not refined and coarse, as kampung dwellers are often described. This idea of refinement has been supported by a complex nexus of values. For example, modes of bodily refinement have been understood as deriving from a Javanese court culture that emphasizes unruffled elegance and grace both in body posture and in the use of the Javanese language. Javanese has several levels that register relative social hierarchy so that speakers must make decisions about relative status in order to use the correct level in conversation 
(Keeler 1984, 1987; Errington 1984). The higher the register, the more distant one is situated from the bump and tussle of social interaction and daily life. The sultan's demeanour is taken to be the epitome of refinement that emphasizes immobility, grace and inner reserve, although it is also the case that the higher one's status the less likely the need to conform to correct status. ${ }^{5}$ That is, the sultan may act as he pleases, while his underlings do not have this freedom of movement.

Even so, some have suggested that the intricacies of learning the Javanese language and the aesthetics of Javanese power serve to distance ordinary men from their families. Their children learn to speak Javanese by using the higher registers for their fathers, implying less emotional closeness. And male potency is concentrated through denial of the material world by avoidance of mundane activities, such as dealing with money. Indeed, taking direct action is a sign of a lack of power and control (Ferzacca 2001). In effect, men are immobilized (Keeler 1987). Note here especially the opposition of male refinement with the gendered ideology of women as unable to attain the kind of aesthetic denial, inner resolve, and remove that are associated with male power. Nancy Smith-Hefner (1988) has noted the tendency for women to hypercorrect when using the Javanese language; that is, they tend to move up in register inappropriately. In fact, their mobility is a liability. Likewise, while their movement through markets as buyers and sellers demonstrates their instrumental efficacy, it is not an ideologically legitimate form of power (Brenner 1998; Peletz 1996; see also Keeler 1984; Smith-Hefner 1988). So the emphasis on refined bodily comportment serves to mark gendered and classed forms of embodiment, but perhaps in surprising ways.

The admonition to not 'act like a kampung person' was mentioned earlier. Attention to child socialization practices shows the key importance of modes of comportment and embodiment as a sign of being a good and moral person. Whatever the case with the royals, it is the upper middle class that is disregarding these forms, often dismissing them as evidence of a feudal past. Yet, in the kampung, these forms of bodily distinction are fully embraced and reproduced, as is evident in child socialization practices. The values of these forms of bodily comportment in the kampung

5 Thanks to Chris Brown for prompting attention to this issue. Indeed, status is like kampung membership, a matter of looking up and down at once (see Keeler 1987 on relative status). And it is important to note that the kampung described here had a close relationship with the Yogykarta kraton and a history of serving as the residential quarter for abdi dalem, those servants of the sultan whose comportment must perforce be alus but who were (and are) quite poor. 
serve as particular markers of class. To attain them and use them is desired by kampung inhabitants, perhaps to counter the view of outsiders. These forms are important to those who would improve their class position, whereas those whose class standing is assured can ignore them.

So young Ari and the other grandchildren were schooled in particular forms of 'registered' bodily behaviour, that is bodily performances that registered status, just as the levels of the Javanese language are based on recognizing status differences. These moments of educating Ari on the porch revealed other aspects of child-rearing. Ari was the youngest grandchild. Consequently, all eyes were trained on him. His refusal to leave the car resulted in a torrent of language directed at him, from mother and father, but also from uncles and aunts, and a variety of cousins. Indeed, for some time the energy of this large group of relatives was directed predominantly at convincing this young boy to leave the car and come greet me. This ongoing harangue was remarkable in several ways. First, this continual bantering, threatening and harassing were part of the normal mode of teasing the young to get them to comply. No physical action was taken, and instead a veritable sea of words surrounded him, urging him to think about the consequences, to consider his actions, to see that this was the wrong choice. He listened silently, and looked with longing at the toy and with terror at me, as the words continued.

The admiration of both the car and the child also serve as markers of class. Not only did the mobil make the family able to move around more freely, the approach to socializing the young Javanese child suggested a concern with middle-class markers of status. H. Geertz (1961; cf. Koentjaraningrat 1985) considered three values or principles as key parts of the socialization of children: wedi, isin and sungkan. The terms can be glossed as fear (wedi), shame (isin) and knowing one's status relative to another - a kind of humility (sungkan). ${ }^{6}$

In Hildred Geertz's analysis these values reflect the growing sophistication of the child's knowledge of social distinction. Experience in the kampung suggests a slightly different focus, but ultimately the same result: a finely tuned sense of position in social space, one that is as relevant to the kampung class as to the priyayi class (Errington 1984). Descriptions of people in the national language as kurang malu (not embarrassed enough)

${ }^{6}$ While isin and wedi are Javanese words, sungkan is an Indonesian word. In Yogya, rikuh or pekewuh would be used for sungkan. People use sungkan in East Java where Hildred Geertz conducted her research. This may account, in part, for the difference of opinion with Koentjaraningrat. My thanks to Nita Kariani Purwanti for pointing this out. 
or nggak tahu malu (doesn't understand what it is to be embarrassed) were used for people who did not know their place. Translated into Indonesian for my benefit, I was instructed in some of these values as well. For example, a young neighbourhood boy who frequently played at my house was from a very humble background. His father was unknown, and his mother was alleged to be a prostitute. Because he was young and full of fun, he was often in my house, intrigued by the foreigner. It was after one of these occasions that my next-door neighbour told me that his behaviour was not sesuai, not fitting. I didn't fully understand at the time that what she meant was that he was not acting appropriately for his social station, which is to say, he was trying to move beyond the status he was meant to have. In other words, his mobility was restricted.

The development of a precise sense of social geographic sense is produced through another value that I saw in practice in kampung child socialization, one that is vitally important to understanding kampung class and its embodiment, and that is the value of learning to ngalah. As Keeler notes, the word 'is based on the root kalah ("to be defeated"), but the initial nasalization gives the word an active and intentional cast, so that it expresses the decision on the part of a stronger or more righteous party to yield voluntarily to another. To be able to ngalah is an ability much praised in Java' (Keeler 1987:62). ${ }^{7}$ In practice, this value means that older children must learn to concede defeat to the younger; they must learn to recognize the greater vulnerability of younger children and learn to deny what they want themselves in favour of giving to younger family members. As one friend described it, to concede defeat, or ngalah, can actually mean to win in the sense of winning over one's desire and attaining maturity. The value of knowing defeat amplifies and reinforces the value of knowing one's social place and not to move beyond it.

Despite the shrinking family and delayed marriage, long-standing Javanese kinship, family and child socialization practices remain quite relevant in the kampung in my experience. Children are raised in households shot through with a network of kin from parents to grandparents to cousins, uncles and aunts. They are the centre of daily discourse and interaction, which subtly encourages them to know their place and to be aware of their social standing. As young Ari gazed at me from the safety and height of his perch in the front seat of the new mobil, he stood for many things: enduring patterns of kinship ties and socialization practices, but also the promise of a new mobility and a new class standing. In the next

7 My thanks to Nita Kariani Purwanti and Gerry van Klinken for their notes on usage. 
section, long-standing practices of child sharing and fosterage and their relevance in the kampung illustrate another form of mobility.

\section{The Circulation of Children}

The term anak angkat - literally lifted child - is often glossed as adoption. The term actually covers various forms of child circulation (cf. Leinaweaver 2008): from child sharing, to child borrowing, to fosterage. Formal adoption is said to be prohibited by Islamic law (Fachruddin 1985; Harahap 1993), although adoptions were reported to me under the name anak pupon (H. Geertz 1961 translated this as adopted child) to mean a formal legal adoption with the severing of ties to the biological family. In this section, these forms of circulation of children are considered in terms of class and the forms of labour flexibility noted above, illustrating again the play between mobility and fixity in social status.

Beatty (2002) makes an argument for Javanese foundational flexibility as a kind of cultural disposition, one that is evident in the practice of moving children between households. As he notes for a community in East Java, flexibility in patterns of adoption share much with patterns of divorce and religious conversion. They all derive, he suggests, from a common cultural scheme that emphasizes the ability to change places and perspectives. Indeed, there are a variety of practices in Java that serve to make children mobile and these practices appear to be long-standing. Boomgaard $(1989,2003)$ considers historical practices that include child sharing (following Henley 2003), adoption and slavery to be contingent on household labour needs. He notes a distinction between anak pupon and anak angkat made in late-eighteenth- and early-nineteenth-century Java. An anakpupon was adopted at an early age and subsequently regarded as a 'normal' child by the adopting parents. This child would receive a share of inheritance and could succeed the adoptive father as a shareholder in the communal rice field. In contrast, an anak angkat was a child brought into the household at a later age that might then work as a servant or farmhand. This child would not inherit. Boomgaard notes some ambiguity in the distinction between resident servants and farmhands and children adopted at a later stage. Over the period 1500-1900 'slavery shaded imperceptibly into adoption', particularly in parts of Sumatra (2003:208). The ambiguity in both cases derives from the blurry line that divides relations driven by affect from those driven by economic need. SchröderButterfill (2004) notes a similar dynamic in her contemporary case studies of child circulation to help with senior care in East Java. Those interviewed 
for the present research also indicated that moving children between households produces a significant tension between love and attention (kasih sayang dan perhatian) and help with paying for school fees and other needs.

In Hildred Geertz's 1961 description, the circulation of children was less clearly about the socio-economic effects than the effects on the household by having a child in the house: to produce a birth, to provide an opportunity for parenting practice, to deal with loneliness. Yet, the term anak angkat commonly used in contemporary Java is clearly about class mobility, and the notion of lifting a child with its implication of obligation shading into economic advantage and redistribution are central to practices of child circulation in Java. In a series of interviews conducted in 2006 regarding the experience of being an anak angkat, it was clear that changes in biological families (due to marriage, divorce or death) were a key reason for the movement of children. ${ }^{8}$ This movement was almost always towards a family that was more economically fortunate. Yet, one aspect of the mobility of children that was repeated in the interviews was movement back to the natal home. In other words, patterns of child movement suggest the circulation of children as markers of possibility, economic and emotional, as well as some of the obstacles to their circulation.

In one case from the interviews, three girls were circulated due to changes in their family of origin. As in all the cases here, this family was a lower-class urban one. These children had quite divergent experiences. It is the contrast between the eldest and the youngest that concerns us here. Their father, a military man, was married four times. Their biological mother was the first, and five children were produced in this marriage. The second wife was fat and very mean (ibu gemukyang sangat galak), according to the oldest girl. The third wife was a Chinese woman who had two children of her own and who was not acknowledged (tidak diakui) by her family because of the marriage. Finally, the fourth wife produced a son.

The three girls were then 'lifted' by a friend of their father, another common way for children to move beyond family. The eldest child never felt accepted and sought to leave this new house as soon as she could. The youngest, who had no memory of the move, was a much-loved and

8 Interviews for this research were conducted by Nita Kariani Purwanti between July and October 2006. Interviews were transcribed by Ms Kariani Purwanti along with a brief synopsis of the life story. The translation of these materials was done by the author. The author extends her heartfelt thanks to Ms Kariani Purwanti, a valued research colleague. 
pampered child in the adopting family. The relationship between the two fathers is telling as to the classed dimensions of anak angkat relations. Both were military men, but the biological father was a lower-status junior officer in a patron-client relationship with the adoptive father. In Java, these hierarchical relationships are described in familial terms. The poorer, lower-status man is child to his senior officer (anakbuah / or, literally, fruit child). Many poor people in my acquaintance hope to become the anak buah of a powerful man, and thus derive the benefits (often economic) in exchange for loyalty (often political). The difference in status was evident when the younger daughter described her relationship with her biological father before she knew that she had been moved: 'At first I called my "real" father Uncle Raji, and he would talk to me in high Javanese. ${ }^{9}$ Her biological father's use of a honorific level of Javanese to speak to her would be unimaginable if not for her movement as a lifted child (see Beatty 2002). In this case the spoiled child, who was moved without, at first, knowing, was treated as a person of higher status than her own biological father. The 'lifting' represented by child movement is quite evident. And yet the story does not end there.

After the death of the adopting father, his fourth wife secured his property for her own child. The grown adoptive daughter went on to say: 'After my adoptive mother died and my adoptive father married again, all his wealth was dominated by [my] step mother, who was evil and greedy, I wasn't given a portion' [from the inheritance of the adopting family]. ${ }^{10}$ This outcome was described as the result of the lack of formal documentation of the transfer, a fact that reiterates the informal character of much of this child circulation. In this case, the youngest daughter returned to her natal home where she was granted inheritance by her 'uncle,' her biological father. Ultimately, both girls received inheritance from their biological father despite the fact that he was of a lower socio-economic status. The sisters now share a house given to them. The reversal of fortune represented by this case is quite remarkable.

The movement of children because of economic need was described again and again in interviews. When there were changes - a death, a remarriage - in the family, often children were moved as a result. In many of these cases, the movement was of a child back to an original home

9 'Dulu kalau memanggil ayah asli "Oom Raji", dulu ayah asli kalau berbicara denganku malah bahasa Jawa halus.'

10 'Setelah ibu angkat meninggal dunia dan ayah angkat menikah lagi semua harta ayah angkat dikuasai oleh ibu tiri yang jahat dan serakah, saya tidak diberi bagian.' 
because of changing fortunes in the adopting family, that is, these movements were indeed circulation. What seems to be a persistent element in the circulation of children is the attempt to tap the resources available and/or implied in patron-client relations. That is, as suggested above, although lifted children are understood to benefit from their movement, in many ways it is their role as nodes in the networks of kinship and patronage that explain the prevalence of these patterns. Their circulation produces and reinforces pathways of exchange. The complicated nature of economic gain as against emotional relation was repeatedly mentioned in interviews. The continued mobility of children, moving as need be to avoid fate and to take advantage of resources, suggests that Beatty's notion of an embrace of different perspectives through socialization of children is true, yet to shear it of attention to class differentiation, as he suggests (2002), is a mistake.

Like the desire of the kampung class to move easily and freely beyond the confines of their lower-class urban neighbourhoods, the circulation of children is about a variety of forms of desire for the free movement through social space. But it is also about a clear attempt to move up the class hierarchy, as we saw in the case of the mobil. Yet, in many ways, this mobility does not represent a jump across a broad divide between haves and have-nots, but rather a kind of lateral, tactical move to open up and make use of rather small differences in social standing. Like the new mobility of the kampung class in terms of transportation and communication, attempts to move beyond are circumscribed by limits and obstacles that relate to embodied forms of distinction that derive in part from economic class and the structure of feeling that shapes it in urban kampung neighbourhoods.

\section{Class Mobility and the Fixity of the Kampung Class}

Flexibility, in the disposition of labour and in social status evident in patterns of child socialization and circulation, might be said to support and extend Beatty's proposal of a fundamental Javanese flexibility. But the cultural disposition proposed here is produced as a form of practical consciousness; one born of the structuring power of the reproduction of precarious and abundant labour to the great advantage of the Indonesian state and economy. This is no argument for the role of culture as a sui generis phenomenon, but rather an argument about the deep imbrication of culture and class. Referencing Raymond Williams's long revolution in 
the structure of feeling, not to mention its relationship to state power (Corrigan and Sayer 1985), this approach to mobility appreciates not only its local valence, but also its powerful shaping by a global political economy and a national state.

Although the kampung class may desire a middle-class mobility and may circulate children as mobile tokens of economic opportunity and of pathways of exchange and obligation to achieve a kind of upward mobility, there is much that fixes this class in place, despite their efforts to move beyond. First, the flexibility of labour that serves the comparative advantage of Indonesia depends on the fixed labour of kampung women as national heroes of reproduction and domestic engineering, even after the end of the New Order. Their fixity through state-sponsored domesticity relies on a tightly circumscribed sphere of mobility, the kampung community, even as the unemployed and under-employed labour of others in the kampung is made absolutely mobile and flexible. These programmes, as well as the precarity of economic life for this class, are linked as well to the house-based micro-enterprise industries of the informal sector that sponge excess of labour in surplus-labour economies.

Yet, there is a real irony here in the forms of kampung flexibility and mobility in labour, in child sharing, in community welfare work: they are founded on the stable reproduction of the lower class. And this stability, this fixed location in the social space of Indonesia, is strangely reiterated, not only in forms of child socialization, but also in the circulation of children to take advantage of economic difference and in their ultimate return to where they began. As young Ari sits in the front seat of the family's new mobil, he seems the very epitome of the promise to move up to the middle. After all, his father and mother have moved to one of the new housing developments in the suburbs, and their new car allows for forms of urban mobility that were once denied them. At the same time, some forms of public transportation available to the urban poor are being undercut by recent changes, including the end of subsidies on petrol for motorbikes and the proliferation of cell phones and texting. ${ }^{11}$ Yet, in truth, the mobility of the kampung class has long been limited. This is evident in the social value placed on knowing one's place. The socialization of kampung children illustrates the continuing importance of family, including aunts, uncles, cousins and grandparents as well as parents, fifty years after Hildred Geertz's work. It also shows the continuing role of child-rearing

11 Thanks to Fridus Steijlen for these notes on changes to public transportation. 
that emphasizes the importance of respect, of embodied social subjectivity and forms of distinction, and of the importance of conceding defeat, mengalah, and knowing one's place. While forms of respectful embodiment might easily be denigrated as the feudal remains of Yogyakarta's colonial nostalgia for aristocratic privilege, the modes of child-rearing in the kampung derive more proximately from cultural practices that register a desire for middle-class status, even as they index forms of embodied distinction defined in the ongoing reproduction of these lower-class enclaves.

The circulation of children in urban kampung illustrates how local forms of embodiment serve to mediate class, and class-striving, in everyday life as against the state's advantage in the continued precarity of daily economic life. 